\title{
"UMA MULHER QUE NUNCA VERGAVA; QUE NÃO TINHA AMO NEM DEUS" - recortes da mítica rainha Nzinga na literatura de Agualusa, Mussa e Eugénia Neto
}

\author{
Marcele Aires Franceschini \\ (Universidade Estadual de Maringá)
}

\section{RESUMO}

A mítica Nzinga Mbandi, a Rainha Ginga, foi líder de vastíssimo território no século XVIII. Grande parte dos escravizados que vieram ao Brasil são oriundos da região bantu - dominada por ela então. Sua história é tão gloriosa quanto a da própria África. Não por acaso inúmeros são os historiadores que se interessam por sua figura, assim como centenas são os escritores que já se aventuraram a romancear ou a cantar seus feitos. Para essa análise, escolheram-se três autores: o angolano José Eduardo Agualusa e seu romance histórico A Rainha Ginga: e de como os africanos inventaram o mundo (2014); o carioca Alberto Mussa e seu romance policial $O$ trono da Rainha Jinga, (1999); e a portuguesa radicada em Angola Eugénia Neto e seu poema "Poema à Mãe Angolana", lançado em 1976, no contexto da luta pela Independência de Angola. Prezaram-se, nesse estudo, dois movimentos: primeiramente, descreveu-se historicamente a figura da Rainha para então a retratar segundo recortes dos autores supracitados. Ambos Agualusa e Mussa tendem a demonstrar o poder da Rainha representado por sua força "de macho", já que a líder assume a governança marcada pela linhagem patriarcal. Já Eugénia Neto humaniza a figura de Nzinga como a grande "Mãe Angolana", salientando suas características femininas. Independente do julgamento, importa perceber como autores de distintas nacionalidades e gêneros constroem a imagem da soberana africana, mesclando história e ficção num balé fértil de dimensões épicas e poéticas.

PALAVRAS-CHAVE: Rainha Ginga, Agualusa, Mussa, Eugénia Neto. 


\section{Surreal biografia}

Poucas rainhas se tornaram tão míticas quanto Nzinga Mbandi (1582-1663), a Ngola Mbande Nzinga Bandi Kia Ngola, ou simplesmente a Rainha Ginga, como conhecida no Brasil. Exímia estrategista, ordenava ser chamada de "Rei", Ngola - daí o significado do nome "Angola" (THORNTON, 1991, p. 25-40). Temida pelos portugueses, conduziu seus exércitos até os 73 anos. Angola só seria tomada após sua morte, aos oitenta e um (CAVAZZI, 1965; MILLER, 1975).

Sua história confunde-se com o próprio destino de Angola: por volta de 1580, ou dois anos antes do nascimento da rainha, é deflagrada a guerra do Ndongo contra os portugueses. Filha do Ngola Mbande Ngola Kiluanji com uma escrava, desde criança Jinga fora treinada ao manejo de armas e ao combate. Segundo o material pedagógico Nzinga a Mbande, produzido à série "Mulheres na história de África" (UNESCO, 2014), com apenas oito anos a menina teria acompanhado o séquito do pai em uma batalha - parte dos aprendizados de guerra. Eis um dos primeiros exemplos de como a vida da Ngola Nzinga paira em territórios míticos: a criança guerreira não nasce intocável, frágil como as princesas medievais. Ao contrário: desde a infância mostra-se íntima da soberania paterna, natural e duplamente, "Ngola" e "Kiluanji", ou "Líder Político" e "Chefe do Exército" (KWONONOKA, 2014, p. 63).

Educada na conduta marcial, tanto o ímpeto quanto a diplomacia iriam tecer a vida de Nzinga Mbandi, cuja homofonia/homografia "homem-mulher" se revela fértil na parte oriental de Angola (SOUINDOULA, 2012, p. 103). Apesar de alfabetizada em língua portuguesa por padres jesuítas que doutrinavam na região, Nzinga manifestou forte resistência ao domínio estrangeiro - muito embora não tenha assumido o trono imediatamente com o assassinato do pai, em 1617. Pois ainda que em diversos territórios africanos as sociedades se mantivessem matrilineares, as mulheres não exerciam o poder, visto que as funções mais "respeitáveis" eram destinadas ao homem (MUNANGA, 1996, p. 61). Por isso, quem ascende ao trono de Ndongo após a morte do pai é seu irmão, Kia Mbandi:

$\mathrm{Na}$ África bantu não era comum uma mulher, em sociedades tipicamente machistas, embora matrilineares e gerontocráticas, uma mulher com intrepidez, sagacidade, capacidade diplomática e sem preconceitos feministas, dirigir um Estado, papel reservado tradicionalmente aos 
homens e aos mais velhos, ligados ao sangue, valor ou descendência real (KWONONOKA, 2014, p. 61).

No entanto, Jinga Mbandi sempre teve grande representatividade política em sua terra. Pantoja (2014) observa a figura mítica da soberana do Ndongo no imaginário de seus contemporâneos: "As narrativas de tradição oral do povo mbundu descrevem a rainha Nzinga Mbandi como temida pelos seus súditos e inimigos, $[\ldots]$ vencedora das batalhas mais estupendas contra os europeus" (p. 115). Assim, temeroso de perder o poder, o agora Ngola Mbande manda matar o filho único de Jinga, Quizua Quiazele - cuja tradução equivale a "Dia Claro" (citado em AGUALUSA, 2015, p. 39). Apesar de nascido bastardo, era um forte pretendente ao trono. Para acabar com a linhagem das irmãs - Njinga, Nfungi e Nkambu -, o sádico irmão teria ordenado que seus úteros fossem mutilados com água fervente e ferros em brasa (PINTO, 2015, p. 316).

No ambiente inóspito, violento, seguem-se anos de derrotas do novo rei em confronto com os portugueses: terras são devastadas, fome por todos os lados, homens, mulheres, crianças e velhos traficados, sobretudo ao Brasil. Como analisa Candido (2013, p. 267), o tráfico afetou não só os capturados e enviados às Américas, mas também os que permaneceram no continente africano, sob ameaça inexorável do cativeiro. Guerras, razias e sequestros teriam levado à fragilidade e ao colapso das relações políticas, bem como à legitimação da instituição da escravidão. Joaquim Nabuco, no capítulo "O tráfico de africanos" de O abolicionismo (1883), revela números do tráfico ao território brasileiro: "O poder, porem, do Trafico era irresistivel e até 1851 não menos de um milhão de Africanos foram lançados em nossas senzalas. A cifra de 50,000 por anno não é exagerada" (2011, p. 136).

Dois séculos antes da contabilidade de Nabuco a situação já se mostrava insustentável nos domínios africanos: em 1618, um ano após o assassinato do pai de Ginga - apesar do ódio pelo algoz irmão -, a futura rainha do Dongo e de Matamba tem consciência de sua importância político e militar na dinastia, por isso toma frente para tratar de assuntos diplomáticos e possíveis tratados de paz com o governador português. Obtendo sucesso em sua empreitada, Correia de Sousa teria mantido negociações com Ginga ao longo de 1622, tendo a instruído na conversão ao cristianismo: “[...] abraçou a nossa santa fé e [...], com 40 anos de idade, foi solenemente batizada na Sé de Luanda, tendo como padrinho o governador [...]" (CAVAZZI, p. 69, v. 2, livro V). 
Entretanto, sua adesão aos preceitos católicos e a consequente adoção do nome português "Dona Ana de Sousa", por mais que vista como uma atitude de fé pelo Padre Cavazzi, não passou de estratégia da líder africana. A tal "conversão" seria prontamente renegada um ano depois, em 1663, quando Portugal descumpriu acordos com os bantos. No mesmo ano, o irmão, após sofrer grandes derrotas, foi envenenado por ela nas ilhas do Kuanza (ROCHA, 2011, p. 854). Agora Rainha, Nzinga-Mbandi-Ngola une-se aos temidos antropófagos jagas, casando-se com seu líder. O bando compunha-se de guerreiros de povos vencidos, de modo que não havia uma formação de linhagens, como costume dos demais povos da região. Cadornega observa que os kilombos não eram formados por linhagens - ao contrário, as hierarquias pautavam-se pelas conquistas de guerra (citado em PARREIRA, 1989, p. 153).

Ao se tornar a Rainha do Ndongo e da Matamba, unindo-se aos jagas, há fatos ainda mais míticos relacionas a sua figura: além de se vestir com trajes masculinos e exigir ser chamada de "rei" (Ngola), tinha um exército de escravos sexuais, cerca de "trezentos jovens de ambos os sexos, divididos em seis grupos, vestidos com trajes do sexo oposto e que praticavam o sexo livre" (BRÁSIO, v. 12, p. 469-472 apud MACEDO, 2013, p. 61).

No entanto, dois fatores levaram a Mbandi a deixar os jagas e a se voltar contra as forças portuguesas: primeiramente, fora traída pelos guerreiros canibais; e, na sequência, diante do plano de conquista de Angola pela Companhia Neerlandesa das Índias Ocidentais, uniu-se aos holandeses. A aliança se deu justamente na época em que a Companhia dominava o Nordeste brasileiro. Tal parceria teria durado sete anos: de 1641 a 1648, quando Gaspar Borges de Madureira derrotou as forças de Nzinga, aprisionando sua irmã, Dona Bárbara (GRAZZIANO, 2013; MATA, 2012).

Com a reconquista definitiva de Angola por Salvador Correia de Sá e Benevides, a soberana isolou-se em Matamba, onde continuou a resistir até se converter novamente ao catolicismo em troca da liberdade da irmã. Em 1659, aos setenta e sete, Jinga-Mbandi assinou um novo tratado de paz com Portugal. Após sua morte, em 1663, sete mil de seus soldados foram traficados ao Brasil. Os portugueses só passariam a controlar a área em 1671 (SERRANO, 1996, p. 141). 


\title{
2. A Mbandi no inventário literário: Agualusa, Mussa e Eugénia Neto
}

\author{
Quando eu voltei, \\ os braços dos homens \\ a coragem do soldado \\ os suspiros dos poetas \\ tudo, todos tentavam erguer bem alto \\ acima das lembranças dos heróis \\ Ngola Kiluanji \\ Rainha Ginga \\ todos tentavam erguer bem alto \\ a bandeira da independência. \\ (NETO, 1980, p. 17)
}

Os versos que abrem esse subitem, presentes no poema "O içar da bandeira", foram escritos por Agostinho Neto, na Cadeia do Aljube, em Lisboa, em agosto de 1960. Apesar de as manifestações de solidariedade diante do seu consultório médico e na sua aldeia, houve repressão esmagadora pela Polícia Internacional e de Defesa do Estado (PIDE), de Salazar. Não por acaso, um dos mais aclamados versos do primeiro presidente angolano e que marcam a luta contra o colonialismo resgatem a imagem da Rainha do Ndongo e da Matamba.

Quinze anos depois do poema de Agostinho Neto, Manuel Pedro Pacavira publica o romance Nzinga Mbandi. Escrito entre 1972 e 1974, quando o autor "residia na prisão do Tarrafal, em Cabo Verde", segundo as palavras irônicas de Mata (2014, p. 24-25), o livro destaca-se por seu "pioneirismo na tematização explícita do passado" e de sua "intenção, a começar pelo título, [de] provocar a inversão da imagem portuguesa que representava a rainha africana" (idem, p. 26).

Inúmeros são os textos de origem escrita, acadêmica, literária, cinematográfica e oral que reproduzem a mítica trajetória da soberana africana (Cf. MATA, 2012, p. 23-46). Para essa análise, foram escolhidos recortes de três fontes: A Rainha Ginga: e de como os africanos inventaram o mundo, publicado pelo angolano José Eduardo Agualusa, em 2015; $O$ trono da Rainha Jinga, lançado pelo carioca Alberto Mussa em 1999; e o "Poema à Mãe Angolana", da portuguesa radicada em Angola e viúva de Agostinho Neto, Eugénia Neto. Num primeiro momento, pode-se notar que tanto nos romances quanto no poema a apresentação/representações 
de Ginga transitam entre o histórico e o épico. Desde o início do romance, a protagonista de Agualusa exibe seu poder, enérgica, jamais mulher a abaixar a cabeça, submissa:

[...] ostentava sobre os ombros uma capa vermelha de apurada oficina, e aquela capa parecia fazer refulgir seu rosto, como se um incêndio a consumisse. Ginga discutia em alta voz com o irmão, como ele partilhasse a mesma vigorosa condição de macho e de potentado. Já na altura não admitia ser tratada como fêmea. E era ali tão homem que, com efeito, ninguém a tomava por mulher (AGUALUSA, 2015, p. 12-13).

Já nas primeiras linhas o leitor se deixa levar pela construção mítica da soberana, em especial pela capa vermelha, que evoca, de modo geral, a presença do[a] guerreiro[a], coragem e força. O vermelho é fogo, é sangue, é paixão, é beleza (CIRLOT, 1984, p. 570). Na mitologia das máscaras e capas africanas, o vermelho é símbolo "ambivalente, pois representa o sangue, o fogo, o sol [...], a fecundidade e o poder" (KIUNDUNDULU, citado em ADOLFO, 2009). Além desse detalhe, Ginga assume dupla identidade ao longo de toda a obra, seja pela "vigorosa condição de macho", "tão homem", seja por ser

Tão viril quanto o homem mais macho. Uma mulher que nunca vergava; que não tinha amo nem Deus. Uma mulher que conhecia as artes da guerra, as suas armadilhas e danações [...], pois sabendo cogitar como um homem, possuía a seu favor a sutil astúcia de Eva (AGUALUSA, 2015, p. 83-84).

Eis a Ginga "tão virial quanto o homem mais macho", conhecedora das "artes da guerra". Tanto o é que Kwononoka enumera as várias batalhas que a Rainha participou:

Batalha de Ngolomen-a-Kaita (nome de um soberano aliado da rainha; Batalha de Senga a Kavangaen, 1646. A rainha enfrentou 20 mil soldados portugueses, do Ngola Ari de Kabuko já Ndonga e emcapasseiros (soldados africanos com armas de fogo). A rainha aliou-se com os sobas Ifamuto e Kakulo Kayenda. A rainha foi derrotada; Batalha de Lumbo em terra de Kakulo Kahoji. A rainha contou com o apoio do Ntotila Nkanga a Lukeni, os portugueses foram derrotados; Batalha de Ilamba a 1 de agosto de 1648 contra o exército de Luanda. Morreram todos os oficiais portugueses, o capitão-mor Filipe Ngola Ari, filho Fo Ngola, rei do Ndongo; Batalha de Wandu, onde os portugueses foram igualmente esmagados (KWONONOKA, 2014, p. 65). 
Neste universo, a Nzinga-Mbandi de Agualusa tanto negocia quanto articula os planos de guerra assumindo sua porção "masculina", voltada ao ímpeto da guerra, porém, munida da "sutil astúcia de Eva" (AGUALUSA, 2015, p. 84). Em seu "estado bruto", a líder angolana é igualmente descrita em $O$ trono da Rainha Jinga: "A rainha pretendia endurecer as escaramuças com o Jaga Cassanje e decidira fechar os mercados de escravos - todos que pudesse, de Matamba ao alto Cuanza" (MUSSA, 2011, p. 7); "Falavam da guerra com os jaguas e dos planos de Jinga para enfraquecer o irmão" (idem, p. 7); "Mas Ana resolver exagerar [...]. Quis desafiar abertamente os homens da Coroa. Provocou asco, suscitou ódio, feriu vaidades" (idem, p. 15). Quanto à vingança do suposto assassino do filho, a rainha ordena: "Não basta matar. É preciso provocar dor" (idem, p. 7).

Ambos Agualusa e Mussa contemplam o ímpeto e o enrijecimento de Ginga; ao passo que Eugénia Neto a descreve de um modo menos beligerante, onipotente, mais a fim do humano: a primeira das mães de sua terra - daí o título: "Poema à Mãe Angola":

Avança Mãe Angolana

E dá o melhor de ti própria

Nesta luta de vida ou de morte

Avança pelos rios perigosos

Pelos pântanos lodosos

Pela savanas sem fim

Avança pelo incomensurável horror da guerra Entre a chuva de bombas que ilumina a terra

Mas avança porque é necessário

Avança com teus braços feitos asas

Abertas sobre o solo pátrio

Para proteger os teus filhos

Não te detenhas nos gemidos do vento

Não prendas à forma das flores

Sublima o amor neste momento

Avança Mãe Angolana

Que a tua coragem fará vacilar os soldados

Os soldados que já foram meninos

Os soldados

A que o fascismo tolheu a vontade 
E que caminham sobre os cadáveres das crianças

Com risos sarcásticos de vingança...

Avança Mãe Angolana

$\mathrm{Na}$ terra ensopada de sangue

Dor e lágrimas

Causadas pela guerra

Que ela florescera

Sustentada pelo teu querer

E terás para os teus filhos

O sol aberto nas pétalas

E a serenidade dos heróis

Depois de ganha a batalha.

(NETO citada em PEREIRA, 1999, p. 122).

Publicado em onze de novembro de 1976 no Jornal de Angola, o poema é celebrado no mesmo ano em que Eugénia Neto lançou o livro Foi esperança e foi certeza. No contexto do recém-liberto país, o texto mantém seu sentido solene e épico sobretudo porque, de 1975 a 1979 seu marido, o médico e escritor Agostinho Neto assume o governo. Assim, impossível deixar de sentir a carga política que predomina em sua poesia: apesar de ter nascido em Trás-os-Montes, Portugal, foi uma das intelectuais mais engajadas pela libertação angolana, sendo a única mulher a assinar o ato constitutivo da União dos Escritores Angolanos (UEA) - a primeira editora do país (FERNANDES, 2008, p. 2-3).

No entanto, seu épico foge do estereótipo de semideusa - já nos dois primeiros versos a poeta evoca a figura da Rainha como se o se dirigisse à qualquer "mãe angolana: "Avança Mãe Angolana / E dá o melhor de ti própria". Apesar de o substantivo e o adjetivo pátrio estarem marcados pelas iniciais maiúsculas, indicando certa exclusividade à Rainha, qualquer tentativa de univocidade à soberana cai por terra, visto que Eugénia Neto destaca o verbo no imperativo: "Avança" (diga-se de passagem, repetido sete vezes ao longo do poema). A ênfase no imperativo exprime ação, deslocando-se a voz do eu-lírico do passado ao presente, sendo completada pelo valor de intimidade propiciada pelo pronome pessoal: "E dá o melhor de ti própria". Há um claro movimento do passado ao presente - e vice-versa, sobretudo na terceira estrofe, quando a "Mãe" não surge apenas como guerreira mítica, porém com "asas abertas" para 
"proteger" seus "filhos": "Avança com teus braços feitos asa / Abertas sobre o solo pátrio / Para proteger os teus filhos".

$\mathrm{O}$ cientista político camaronês Achille Mbembe, em "As formas africanas de auto-inscrição", reconceitualiza a noção de presente ao afirmar

Já que o tempo em que vivemos é fundamentalmente fraturado, o próprio projeto de um resgate essencialista ou sacrificial do eu está, por definição, fadado ao fracasso. Apenas as diversas (e muitas vezes interconectadas) práticas através das quais os africanos estilizam sua conduta podem dar conta da densidade da qual o presente africano é feito (MBEMBE, 2001, p. 200).

Sob tal prisma, é natural que a identidade de Nzinga Mbandi seja multifacetada, afinal, distintos autores cantam/contam/recriam seus feitos. Assim, absorta num mundo de "posição ambígua da mulher dividida entre a natureza e a cultura" (ORTIGUES, 1989, p. 207), a Rainha deixa seu lado bruto, revelando-se também candidez, sabedoria, luxúria, imagem lasciva de uma deusa. Não obstante, as primeiras palavras que abrem o romance de Agualusa trazem, igualmente, uma mulher iluminada, quase uma entidade mítica em contato com o mar, a exemplo da passagem relatada pelo escrivão de Ginga, o Padre Francisco José da Santa Cruz:

A primeira vez em que a vi, a Ginga olhava o mar [...].

$\mathrm{Na}$ manhã em que pela primeira vez vi a Ginga, fazia um mar liso e leve e tão cheio de luz que parecia que dentro dele um outro sol se levantava. Dizem os marinheiros que um mar assim está sob o domínio de Galena, uma das nereidas, ou sereias, cujo nome, em grego, tem por significado calmaria luminosa, a calmaria do mar inundado de sol.

Aquela luz, crescendo das águas, permanece na minha lembrança, tão viva quanto as primeiras palavras que troquei com a Ginga (AGUALUSA, 2015, p. 9-10).

Tal e qual, o narrador de Mussa também descreve o poder da Rainha no dia em que a conheceu: "Foi em 1619 que vislumbrou pela primeira vez aquela mulher impressionante. Jinga - que se proclamava soberana do Ndongo e de Matamba" (2011, p. 3). Apesar de destacar o tom sombrio de assassinatos e suspenses que entremeiam sua prosa, e ainda que informe no posfácio de que não se trata de um romance histórico, baseado em pesquisas sistemáticas, e que a interpretação de seus personagens é "ten- 
denciosa, arbitrária e pessoal" (idem, p. 38), o autor carioca não deixa de a construir como modelo de astúcia, inteligência e perspicácia, deixando correr a criação da protagonista: "- Veja esta pedra e tente destruí-la. Talvez alguém consiga transformá-la em pó. Mas esse pó ainda continuará enchendo a minha mão. O mal é como a pedra ou qualquer outra coisa: não se perde; não se cria. Apenas muda de lugar" (idem, p. 7).

Nesta passagem, Mussa enreda pelos caminhos da oralidade, ou das crenças populares materializadas em forma de analogias e metáforas que constroem o mito em torno de Jinga: "Acontece serem orais a maior parte das fontes com que os historiadores angolanos se veem obrigados a trabalhar, tal como acontece [...] onde a tradição oral sempre foi a seiva e o húmus das próprias culturas e memórias coletivas" (GONÇALVES, 2013, p. 12). Tal natureza comunicativa acaba criando uma "espécie de pré-história da própria história de Angola" (idem), ou uma narrativa mítica, como concebe Adolfo: "As interferências sobrenaturais, porque vindas de um tempo e de um espaço que não existem mais, só por isso são extraordinárias [...] e a narração apresenta um fato maravilhoso" (2014, p. 61-62). Logo história e mito se misturam no amálgama da tradição africana - forte alicerce presente na cultura brasileira: "No Brasil, os nossos ancestrais africanos enriqueceram a nossa cultura com diferentes expressões e formas de se relacionar com o mundo mágico e sobrenatural" (MUNANGA, 2006, p. 139).

Esse é, de fato, uma leitura bastante percorrida nas pesquisas sobre oralidade africana (CHAVES, 1999; LEITE, 2005; PADILHA, 2007; ADOLFO, 2014). Consequentemente, por sua complexidade de figura história e mítica, a Ngola do Ndongo e da Matamba é personagem multifacetada, plural. "No imaginário da nobreza, a figura de Ginga remete a uma mulher altiva, que desperta o respeito e o temor até mesmo dos inimigos" (OLIVEIRA \& MENDES, 2017, p. 98). Inexoravelmente, "diante dos conflitos bélicos, entre os africanos e o povo luso, no centro do embate, está presente a figura lendária da rainha" (idem, p. 120). Ao caracterizá-la historicamente, Lugarinho (2016) observa:

[...] desponta uma personagem evidentemente controversa que representa a incapacidade de domesticação absoluta do seu poder mítico - seja nas páginas mais antigas, em que os traços diabólicos da rainha Jinga são acentuados, seja em páginas mais recentes em que os mesmos traços são transfigurados para confirmarem um modelo de resistência colonial (LUGARINHO, 2016, p. 92). 
Com efeito, diante da prerrogativa de criar uma heroína africana, portanto épica, mítica, ambos Agualusa, Mussa e Eugénia Neto enredam o fluxo dialógico 'fábula/realidade' em seus discursos, afinal trazem como mote a mítica soberana africana. $\mathrm{O}$ próprio Mussa, em entrevista à revista Cândido, admite: "O traço comum a todas [minhas criações], contudo, continua sendo a base mitológica. Essa é a essência da minha ficção: o mito" (MUSSA citado em REBINSKI JR., 2012). Ele segue sua linha de raciocínio: "Uso a história apenas como mote, como ponto de partida. O resto é ficção, sempre. [...]. É uma forma de envolver o leitor na narrativa, fazendo que ele acredite haver naquilo alguma verdade" (idem). O autor amplia seu entendimento:

O leitor de romance sabe que está lendo romance. Por mais que ele identifique algum aspecto que lhe pareça verdadeiro, é romance. Está dito. Está escrito na ficha catalográfica. Faz parte do jogo, do negócio, do mercado. Quem lê romance gosta de ser enganado. Compra o livro com esse objetivo. E, acho eu, não há nada melhor (MUSSA citado em REBINSKI JR, 13 ago. 2012).

Sobre a temática, Agualusa, em diversas entrevistas, comentou o processo de criação diante da incrível história da Nzinga-Mbandi, em especial porque em vários episódios do livro se surpreendeu com o maravilhoso dos episódios históricos:

Por exemplo, a determinada altura, eu falo de quando os holandeses saem de Pernambuco, depois de a terem conquistado, para tomar Luanda. Quem vai à frente dessa armada é um pirata, o mais famoso pirata da época, tão famoso que os espanhóis lhe chamavam, simplesmente, El Pirata, que é o primeiro caso documentado na história de um pirata com perna de pau. E eu pensei, não posso utilizar o pirata com perna de pau porque as pessoas vão dizer 'não, isso também é demais" (AGUALUSA, citado em RODRIGUES, 10 out. 2015).

Já Eugénia Neto, por humanizar a Rainha, ao torná-la feminina sob o aspecto "maternal", não opta apenas por marcar os grandes feitos e a mítica em torno da Rainha, senão a materializa na "luta de vida e morte" (NETO citada em PEREIRA, 1999, p. 122, verso 3) enfrentada por todas as mães angolanas. Na luta, eis que a "Mãe" avança, forte, "pelos rios perigosos / Pelos pântanos lodosos / Pela savana sem fim" (idem, versos 4, 5 e 6); eis que segue "entre a chuva de bombas que ilumina a terra" (idem, verso 8), "Na terra ensopada de sangue" (idem, verso 24). De fato, a Rainha enfrentou inúmeros percalços em sua existência, no entanto no 
poema os adjetivos relacionados à geografia que percorre são facilmente identificáveis como metáforas das lutas e desventuras que enfrentam as mulheres angolanas - por isso os rios são "perigosos", os pântanos "lodosos" (indicando obscuridade, armadilhas) e a savana "sem fim" (dando ainda mais peso à eterna luta das angolanas).

Lembrando-se que Movimento Popular para a Libertação de Angola (MPLA), liderado por Agostinho Neto, teve como braço a ala feminina Organização da Mulher Africana (OMA), fundada em 1962, cujo "papel socioeducativo foi significativo no período da guerra" (CEVA, 2013, p. 104). Assim que "os textos literários produzidos pelas escritoras tratavam da temática da discriminação e da opressão. Outro aspecto recorrente nas obras era o resgate das tradições culturais, dos mitos e valores africanos" (idem).

Mata (2014) entende o poder de Ginga como símbolo da libertação africana:

Considerada pelos historiadores a maior figura política da história de Angola, a rainha Njinga tornou-se o maior símbolo não apenas da resistência angolana ao domínio português em Angola como da África ao domínio europeu, fazendo ainda parte da memória cultural de todo o mundo afrodescendente das Américas e do Caribe, para onde sua imagem (em testemunhos, lendas, mitos, ecos e ressonâncias) viajou nos porões dos navios negreiros (MATA, 2014, p. 26).

Ao assumir sua porção "máscula", de "Rei” ("A Ginga, agora rainha Ginga, ou melhor, rei Ginga, porque assim exigia ser tratada"; "Ginga se fizera rei”, AGUALUSA, 2015, p. 49 e 53, respectivamente), Jinga faz valer as concepções de cunho biológico/social de Bordieu: "A diferença [...] entre o corpo feminino e o masculino, e, especificamente a diferença anatômica entre os órgãos sexuais, pode ser vista como justificativa da [...] divisão social do trabalho" (2003, p. 20). Assim que Nzinga-Mbandi é a soberana, pois está no lugar mais alto da hierarquia:

Os reinos do Congo e de Ndongo apresentavam uma economia de subsistência, baseada na agricultura, com o desenvolvimento de práticas agrícolas complexas. Essas atividades estavam alicerçadas na mão-de-obra feminina. Produziam objetos de ferro e cobre de alta qualidade, como também de marfim. Criavam galinhas, cachorros e cabritos. A moeda de circulação no território era o nzimbo, uma espécie de caramujo (MACEDO, 2008, p. 40).

As citações sobressaem o fato de que a Rainha, líder dos homens e 
das mulheres, transita entre o factual, de soberana articuladora de guerras e negociações à figura lendária cujo nome cruzou os oceanos e chegou aos ouvidos dos escravos. Condescendentes a esta visão, algo é certo: os romances de Agualusa e Mussa e o poema de Eugénia Neto desprezam descrições ou sentidos "monótonos". Ao contrário: os três autores apresentam descrições "coloridas" pelo exercício da criação em toda sua complexidade. Substancialmente porque a criação do mito é revestida de uma meditação dos detalhes da existência, de tal modo que configura no texto um corpo de ideias, sensações e imagens que traduzem a magnitude de uma Rainha que jamais perdeu sua força. De uma Rainha "que nunca vergava", ou como Mata (p. 35) reconstrói o mito:

A heroicidade da Rainha, uma Muene-Ngola, também se constrói através de descolamentos geográficos vários, e de sua capacidade de convocar outros povos e outros reinos, desde as terras do Kongo às da Lundas e dos Thcokués, do Muene-Kikombo, Muene-Ngunza, Muene-Kambambi, o reino do Ngoyio, as terras de Mbaka, enfim, do norte ao sul, do leste a oeste, rios e montanhas - circunscrevendo territorialmente um corpo simbólico, a dos "povos d'Angola", gerando uma "comunidade imaginada" a partir dessa solidariedade política e de convergência de interesses. É que nesse trânsito geográfico se temperava o seu conhecimento de um território diverso e o fazia convergir para uma causa comum: a diversidade [...] (MATA, 2012, p. 35).

É, pois, no contexto de cartografias/hidrografias dispersas e na diversidade de um povo que a liderança de Nzinga desponta e se mantém. Por isso seu mito se amplia: porque a soberana entendeu a multiculturalidade de seu território, ampliando seu poder na conquista na difusão dos hábitos, dialetos, costumes e crenças. Lembre-se que à época que a Rainha morreu, tinha formado um exército de sete mil soldados (SERRANO, 1996, p. 141).

Mbembe (2001, 2005), imbuído da crença de um cosmopolitismo africano, aponta que a identidade africana não existe estabelecida por vínculos de raça, linhagem ou delimitações espaciais. Para ele, a identidade é plural:

Não é mais suficiente afirmar que apenas um eu africano dotado de uma capacidade narrativa de síntese, ou seja, capaz de gerar tanas histórias quantas forem possíveis a partir de quantas vozes forem possíveis, pode afirmar a discrepância e a multiplicidade de normas e regras interligadas características de nossa época (MBEMBE, 2001, p. 200). 
Seguindo o pensamento de Mbembe (2001) e de Mata (2012), entende-se aqui o empobrecimento de se enquadrar o cânone africano nos limites estabelecidos por "identidade e diferença" ao modo dos gregos, já que a eles o princípio de identidade estava ligado à ideia de propriedade aos semelhantes (MACEDO, 2018, p. 54). Decorre deste viés a impossibilidade de se reproduzir estruturas, categorias e representações criadas no mundo ocidental, edificadas com o intuito de subordinação - jamais de alteridade.

Voltando-se à representação da Ngola no âmbito literário, uma notável diferença entre a representação da Nzinga de Eugénia Neto e dos romancistas é que ambos Agualusa e Mussa enveredam pelo lado da história, ainda que Mussa "tema" admitir tal caminho, tendo em vista que afirmou se guiar na criação da trama e das personagens por História geral das guerras angolanas (1680), do capitão português Antônio de Oliveira Cadornega (MUSSA, 2011, p. 39). Agualusa, por sua vez, deixa claro em seu posfácio que também adotou a obra de Cadornega, além de Descrição histórica dos três reinos do Congo, Matamba e Angola (1687), escrita pelo Padre João Antonio Cavazzi de Montecuccolo, escrivão da rainha.

Os romancistas, ao produzirem a lúdica bricolagem da história com a ficção, fazem coro ao pensamento de Appiah em "African Identities":

Every human identity is constructed, historical; every one has its share of false presuppositions, of the errors and inaccuracies that courtesy calls "myth", "religion", "heresy", and "science", "magic". Invented histories, invented biologies, invented cultural affinities come with every identity; each is a kind of role that has to be scripted, structured by conventions of narrative (APPIAH, 2001, p. 373).

O filósofo anglo-ganês entende que as pressuposições individuais atuam como norteadoras de certas "verdades" no que tange aos processos de resgate e esquecimento sócio-históricos, sobretudo quando estruturadas pela ação narrativa. Ao longo do romance de Agualusa, conclusões morais são lançadas no universo da contação de histórias - a oralidade tão íntima dos povos africanos:

Voltou a sorrir. Ofereceu-me assento numa almofada, a seus pés. Senta-te, ordenou, vou contar-te uma história que meu pai me contou a mim, depois de a ter escutado do pai dele. Aqui, neste chão de África, nós gostamos de contar histórias (AGUALUSA, 2015, p. 35).

Não por acaso, Agualusa abra o livro com dois excertos de cunho 
oral: uma lenda iorubá - "Quando as águas cobriram a Terra e depois nasceram as florestas, sete grandes pássaros, as nossas mães ancestrais, vieram voando desde o imenso além. Três desses pássaros pousaram na árvore do bem. Três na árvore do mal. O sétimo ficou voando de uma árvore a outra"; e um provérbio nyaneka - "A luz com que vês os outros é a mesma com que os outros te veem a ti" (idem).

Não obstante, Eugénia Neto valida a construção do mito histórico: na penúltima estrofe do poema, a "Mãe Angolana" avança "Na terra ensopada de sangue / Dor e lágrimas / causadas pela guerra" (NETO, 1999, p. 122). Entretanto, ao invés de terminar o poema com um sentido épico, a militante opta por humanizar a "Mãe Angolana": "Que ela floresça / Sustentada pelo teu querer / E terás para os teus filhos / O sol aberto nas pétalas / E a serenidade dos heróis / Depois de ganha a batalha" (idem).

$\mathrm{Na}$ última estrofe do poema o imperativo ("Avança") é substituído pelo subjuntivo do verbo no particípio ("Que ela floresça”), mudando-se o sentido de luta, de ação estratégia para expressar o desejo da glória a ser conquistada. E não basta florescer: sua luta jamais será em vão, pois deixará como legado aos "filhos / O sol aberto nas pétalas". Eis o mito da guerreira materna; e não da terrível conquistadora, imbatível; "rei".

Independentemente da $\mathrm{Voz}$ - poética ou prosaica - na reconstrução de Ginga, o que prevalece é o sentido de releitura da tradição do indivíduo africano proposta por Towa em $A$ ideia de uma filosofia negro-africana (2015). O filósofo camaronês argumenta sobre a impossibilidade de se buscar uma imobilização "[d]a tradição e [d]a identidade cultural, pois tudo no universo está submetido a mudanças. E, passando da natureza à cultura e à história, o ritmo de transformação se acelera e muda qualitativamente" (TOWA, 2015, p. 70). Nesse sentido, reler o mito da Rainha Ginga - tanto histórica quanto literariamente - exige o diálogo com inúmeras tradições na perspectiva de articular os temas filosóficos com identidade própria e, uma vez consolidada, transcender a condição que o hegemônico espera de uma tradição subalterna. No caso da soberana africana, uma "mulher que nunca vergava; que não tinha amo nem Deus", como lemos na contracapa do romance de Agualusa.

De fato, a tradição cultural e os mitos de um povo variam segundo os regimes políticos e as organizações sociais, de modo que é somente na diversidade que a unidade e a continuidade podem ser alcançadas. Não há como negar que, apesar de os três escritores aqui selecionados - um brasileiro, um angolano e uma portuguesa radicada na Angola - terem 
origens distintas, o mito da Ginga se vale para todos como "matéria primitiva", cunhando o termo de Foe (2011, p. 219), pois "é somente além da diversidade [...] que a unidade e a continuidade podem ser determinadas e medidas" (TOWA, 2015, p. 193).

\section{"A WOMAN WHO NEVER BENDED; WHO HAD NO MASTER NOR GOD” - CLIPPINGS OF THE MYSTIC QUEEN NZINGA IN THE LITERATURE OF AGALUSA, MUSSA AND EUGÉNIA NETO}

\section{ABSTRACT}

The mythic Nzinga Mbandi, or Queen Ginga, was the leader of a huge territory in $18^{\text {th }}$ century. A large amount of the slaves who came to Brazil are from the Bantu region - dominated by Ginga then. Her story is as glorious as the history of Africa. Not by coincidence a large amount of historians study her, as well as hundreds of writers have already narrated and sung her milestones. For this analysis, three authors were chosen: Angolan José Eduardo Agualusa and his historic novel A Rainha Ginga: e de como os africanos inventaram o mundo (2014); Brazilian Alberto Mussa and his detective novel $O$ trono da Rainha Jinga, (1999); and the Portuguese rooted in Angola, Eugénia Neto, and her poem "Poema à Mãe Angolana", released in 1976, in the background of the war for Independence in Angola. Two movements were outlined here: first, it was historically described the figure of the Queen so secondly we could sketch the clippings of the texts. Both Agualusa and Mussa tend to show the power of Queen represented by her "male" force, once she takes leadership in a context of patriarchal lineage. Nevertheless, Eugénia Neto humanizes the figure of Nzinga as the big "Mother of Angola", marking her female characteristics. Independently of the judgment, this paper aims to notice how authors from distinct nationalities and genders do construct the image of the African ruler, mixing history and fiction in a fertile ballet of epic and poetic dimensions.

KEY WORDS: Queen Ginga, Agualusa, Mussa, Eugénia Neto. 


\section{REFERÊNCIAS}

ADOLFO, Sérgio Paulo. À propósito das máscaras (Trad. de Tata Kisaba Kiundundulu), 18 nov. 2009. Disponível em: http://inzotumbansi.org/home/a-proposito-das-mascaras-traducao-livre-de-tata-kisaba-kiundundulu/, acessado em 14 mai. 2018.

AGUALUSA, José Eduardo. A Rainha Ginga: e de como os africanos inventaram o mundo. Rio de Janeiro: Foz, 2015.

APPIAH, K. A. African Identities. In: BOXILL, B. (Ed.): Race and Racism. Oxford; New York: Oxford University Press, 2001, p. 371-382.

CADORNEGA, António de Oliveira de. História geral das guerras angolanas (1680). Anot. e corrigido por José Matias Delgado. Lisboa: Agência-Geral do U1tramar, 1972, 3 vols., Reprodução fac-similada da ed. de 1940.

CANDIDO, Mariana P. O limite tênue entre liberdade e escravidão em Benguela durante a era do comércio transatlântico. Afro-Ásia [online], 2013, n. 47, p.239-268. Disponível em: http://www.scielo.br/scielo.php?script=sci arttext\&pid=S0002-05912013000100007\&lng=en

$\underline{\text { \&nrm=iso, }}$, acessado em 05 mai. 2018.

CAVAZZI DE MONTECUCCOLO, João António. Descrição histórica dos três reinos do Congo, Matamba e Angola. Trad., notas e índices por Graciano M. de Leguzzano. Introd. bibliográfica por F. Leite de Faria. Lisboa: Junta de Investigações de Ultramar, 1965. 2 vols.

CEVA, Antonia Lana de Alencastre. Intelectuais negras: escrivivências de mulheres brasileiras e angolanas como instrumento de resistência sociocultural. [Tese de Doutorado]. Rio de Janeiro: PUC, 2013. Disponível em http://www2.dbd.puc-rio. br/pergamum/tesesabertas/0912208_2013_completo.pdf, acessado em 17 mar. 2018.

CHAVES, Rita. A formação do romance angolano: entre intenções e gestos. São Paulo: FFLCH-USP, Coleção Via Atlântica, n. 1, 1999.

CIRLOT, J.-E. Dicionário de símbolos. Trad. Rubens Eduardo Ferreira Frias. São Paulo: Edições Moraes, 1984.

FERNANDES, Maria Celestina. Surgimento e Desenvolvimento da Literatura Infantil Angolana Pós-Independência. Anais V Encontro sobre literatura infantil e juvenil. Rio de Janeiro: UFRJ, 2008. Disponível em: http://uenagola.com/index. $\mathrm{php} /$ criticas-e-ensaios/item/301-surgimento-e-desenvolvimento-da-literatura-infantil-angolana-indep.htm, acesso em 13 abr. 2018. 
FOE, Nkolo. A Questão Negra no Mundo Moderno. Sankofa. Revista de História da África e de Estudos da Diáspora Africana, ano 4, n. 8, dez. 2011.

GRAZZIANO; Sérgio (org). Nzinga, Rainha de Angola. Angola: Samba Comunicações, 2013.

GONÇALVES, Zetho Cunha. A escrita da história pela literatura. Mulemba, Rio de Janeiro/UFRJ, v. 1, n. 8, jan./ jul. 2013, p. 12-15. Disponível em: https://revistas.ufrj.br/index.php/mulemba/article/download/4976/34, acesso em 5 mai. 2018. KWONONOKA. Américo. "Njinga Mbandi, Fonte Inspiradora da Mulher Angola”. In:

LEITE, A. Modelos críticos e representações da oralidade africana. Via Atlântica, n. 8, 2005, p. 147-162. Disponível em: https://doi.org/10.11606/va.v0i8.50017, acesso em 14 mai. 2018.

LUGARINHO, Mário César. A apoteose da Rainha Ginga: gênero e nação em Angola. Cerrados, UnB, n. 41, 2016, p. 88-96. Disponível em: periodicos.unb.br/ index.php/cerrados-/article/view/19768, acessado em 23 abr. 2018.

MACEDO, J. R. (org). Desvendando a história da África [online]. Porto Alegre: Editora da UFRGS, 2008 (Diversidades). Disponível em: http://books.scielo.org/ id/yf4cf/epub/macedo-9788538603832.epub., acessado em 12 fev. 2018.

. Jagas, Canibalismo e "Guerra Preta": os Mbangalas, entre o mito europeu e as realidades sociais da África Central do século XVII. História, São Paulo, v. 32, n. 1, p. 53-78, jan/jun 2013. Disponível em: http://www.scielo. br/pdf/his/v32n1/05.pdf, acessado em 07 mai. 2018.

MATA, Inocência. A Rainha Nzinga Mbandi: história, memória e mito. 2. ed. Lisboa: Edições Colibri, 2014, p.115-145.

. Nzinga Mbandi: mulher, guerra e escravidão. Brasília: The-

saurus, 2000.

(org.). Representações da Rainha Njinga/Nzinga na literatura angolana. In: A Rainha Nzinga Mbandi: história, memória e mito. Lisboa: Edições Colibri, 2012, p. 23-46.

MEIRELES, Maurício. José Eduardo Agualusa lança no Brasil 'A rainha Ginga'. Cultura, O Globo, 18 mar. 2015. Disponível em: https://oglobo.globo.com/cultura/livros/jose-eduardo-agualusa-lanca-no-brasil-rainha-ginga-15624385, acessado em 11 nov. 2017.

MILLER, Joseph. C. A . "Nzinga of Matamba in a new persective". In: The Journal of African History, v. 6, n. 2, 1975.

MUNANGA, Kabengele; GOMES, Nilma Lino. O negro no Brasil de hoje. São 
Paulo: Global; Ação Educativa, 2006.

. "Origem e Histórico do Kilombo em África”. Revista USP, São Paulo, 1996, n. 28(2), p. 56-63.

MUSSA, Alberto. O trono da Rainha Jinga. Rio de Janeiro: Record, 2011 (versão epub/DRM).

NABUCO, Joaquim. “O tráfico de africanos”. In: O Abolicionismo. Introd. Izabel A. Marson e Célio R. Tasinafo. Brasília: Editora UnBrasília, 2011, p. 131-140.

NETO, Agostinho. O içar da bandeira. In: O Içar da Bandeira. Loanda: Lavra e Oficina, 1980.

NETO, Eugénia. "Poema à Mãe Angolana”. In: PEREIRA, Carlos Pinto (org.). Do Rovuma ao Maputo: antologia de autores africanos. Disponível em: http:// ebooksbrasil.org/nacional/rebeditions.html, acesso em 20 mai. 2018.

OLIVEIRA, M. D. S.; MENDES, A. de M. A representação do poder feminino no romance Rainha Ginga, de Agualusa. Caderno Seminal Digital, n. 27, v. 1, jan./jun.2017, p. 93-122. Disponível em: www.e-publicacoes.uerj.br/index.php/ cadernoseminal/article/view/28516, acesso em 5 mai. 2018.

ORTIGUES, Marie Cécile e Edmond. Édipo africano. São Paulo: Escuta, 1989.

PACAVIRA, Manuel Pedro. Nzinga Mbandi. Lisboa: Edições 70, 1975.

PADILHA, Laura. Entre voz e letra: o lugar da ancestralidade na ficção angolana do século XX. 2. ed. Niterói: EdUFF; Rio de Janeiro: Pallas Editora, 2007.

PANTOJA, Selma. "Revisitando a Rainha Nzinga Histórias e Mitos da História". In:__. PARREIRA, Adriano. Economia e sociedade em Angola na Época da Rainha Jinga. Lisboa: Editorial Estampa, 1990.

PINTO, Alberto Oliveira. História de Angola: pré-história ao início do século XXI. Lisboa: Mercado das Letras, 2015.

REBINSKI JR, Luiz. "Meu destino é ser outsider". Cândido - Jornal da Biblioteca Pública do Paraná, Curitiba, 13 ago. 2012. Disponível em: http://www.candido.bpp.pr.gov.br/modules/conteudo/conteudo.php?conteudo=34, acessado em 24 mai. 2018.

ROCHA, Denise. Imagens da diplomacia de Nzinga Mbandi Ngola, em Luanda, no ano de 1621: história, gravuras, e narrativa (Pepetela). Anais do III Encontro Nacional de Estudos da Imagem, 03 a 06 mai. 2011, Londrina/UEL. Disponível em: http://www.uel.br/eventos/eneimagem/anais 2011/trabalhos/Denise $\% 20$ Rocha-UNITINS.pdf, acessado em 04 mai. 2018.

RODRIGUES, António. "Não há uma maneira de ser angolano, há vinte e tal milhões". Rede Angola, 19 out. 2015. Disponível em: http://www.redeangola.info/ 
especiais/nao-ha-uma-maneira-de-ser-angolano-ha-vinte-e-tal-milhoes/, acesso em 12 abr. 2018.

SERRANO, Carlos. Ginga, a rainha quilombola de Matamba e Angola. Revista USP, São Paulo, n. 2 8, p. 136-141, dez./fev. 1995-96. Disponível em: http://www. revistas.usp.br/revusp/article/view/28370/30228, acessado em 14 mai. 2018.

SOUINDOULA, Simão. A Rainha Nzinga: uma figura lendária, patrimônio da humanidade. In: A Rainha Nzinga Mbandi: história, memória e mito. Lisboa: Edições Colibri, 2012.

THORNTON, John. Legitimacy and political power: Queen Njinga, 1624-1663. Journal of African History, 1991.

TOWA, Marcien. A ideia de uma filosofia negro-africana. Trad. Roberto Jardim da Silva. Belo Horizonte: Ed. Nandyala, 2015.

UNESCO. Nzinga a Mbande: A Rainha do Ndongo e do Matamba. Paris: 2014 Disponível em: http:/unesdoc.unesco.org/images/0023/002309/230931por.pdf, acesso em 20 mai. 2018. (Série Mulheres na História de África).

Recebido em: 31/08/2018

Aceito em: 21/01/2019 